\title{
CONVERSES A L'INFRAMON, UN CONTRAPUNT DE LA HISTÒRIA
}

\author{
PILAR GÓMEZ \\ Universitat de Barcelona \\ pgomez@ub.edu
}

ORCID: 0000-0001-6560-2836

RESUM

La presència d'herois, encara vius, a l'Hades és testimoniada, en la literatura grega, des d'Homer. Els herois que sense haver mort hi davallen, ho fan sovint per adquirir algun tipus de coneixement. Amb els seus Diàlegs de morts, ben coneguts i imitats en la tradició literària europea, Llucià de Samòsata fou l'iniciador d'un gènere en què l'Hades esdevé un escenari literari on desfilen herois del mite o personatges històrics, l'actitud dels quals, un cop morts, ofereix a l'autor una perspectiva privilegiada per observar amb ulls crítics el món dels vius, la seva societat i cultura, l'exercici del poder, la pràctica de la religió, o el comportament humà més universal i arrelat en totes i cadascuna de las activitats de la vida dels homes. En aquest treball, prenent com a referència la figura d'Alexandre el Gran, analitzarem com l'espai d'alteritat, ucrònic i utòpic, que representa el més enllà llucianesc, ha servit, encara que amb intencions distintes, a autors tan dispars com Fénelon o Borges per fer èmfasi en la conducta d'un personatge o per donar una personal visió d'un determinat fet històric.

PARAULES CLAU: Llucià, Fénelon, Borges, diàlegs de morts, Hades.

\section{CONVERSATIONS IN THE UNDERWORLD: A COUNTERPOINT TO HISTORY}

\section{ABSTRACT}

In Greek literature, the descent of heroes to Hades while still alive is known from the time of Homer onwards. Often, these heroes go down to Hades to acquire some kind of knowledge. In his Dialogues of the Dead, well-known and much imitated in the European literary tradition, Lucian of Samosata initiated a genre in which Hades becomes a literary scenario populated by mythical heroes and historical figures. Their behaviour after death offers the author a privileged viewpoint from which to observe the world of the living, society and culture, the ruling powers, religious practices, and the universal conducts ingrained in all human activities. This paper takes as its starting point the figure of Alexander the Great and explores how the uchronic and utopian space of otherness in Lucian's representation of the afterlife was later exploited by authors as different as Fénelon and Borges in order to emphasize a character's behaviour or to give a personal view of a certain historical event.

KEYWORDS: Lucian, Fénelon, Borges, dialogues of the dead, Hades. 
La forma literària inaugurada per Llucià de posar en escena, en peces relativament breus, dos o més personatges dialogant a l'Hades, ha gaudit i encara gaudeix d'una llarga tradició. ${ }^{1}$ Aquest treball està dedicat al professor Pau Gilabert, qui ha focalitzat en la tradició clàssica una part no petita de la seva tasca de recerca, docència i divulgació a l'entorn del món grec antic. Per tant, - encara que només sigui a tret de pinzellada - voldria mostrar-hi dos testimonis de la pervivència d'aquest gènere llucianesc, el qual - segons els escolis inicials als

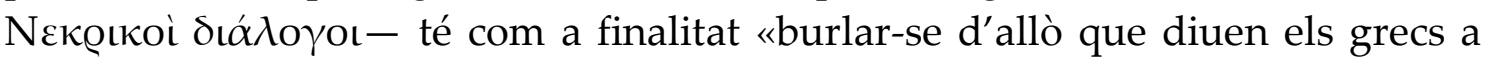
propòsit de l'Hades» i, en conseqüència, Llucià «hi presenta morts conversant entre ells», d'on deriva el nom de Diàlegs de morts. ${ }^{2}$ Aquests morts del samosatenc són figures del mite, personatges històrics, individus anònims.

El punt d'encontre entre Llucià, Fénelon i Borges, malgrat les dissimilituds en molts d'altres aspectes de la seva respectiva producció literària, és el fet que les converses d'ultratomba d'aquests tres autors, a les quals em referiré, presenten homes de la història implicats en l'exercici del poder.

\section{LLUCIÀ DE SAMÒSATA (S. II DC)}

En els Diàlegs de morts de Llucià, Alexandre el Gran és el personatge històric que més vegades hi apareix; concretament, en tres de les trenta peces ${ }^{3}$ que integren aquest grup dels dialogi minores, el rei de Macedònia n'és un dels interlocutors: es tracta dels diàlegs Filip i Alexandre, Diògenes i Alexandre, i Alexandre, Anníbal, Minos i Escipió. ${ }^{4}$ Aquest últim diàleg és plantejat com la il·lació de dos discursos de defensa pronunciats respectivament pel macedoni i el cartaginès davant del jutge de l'inframon, Minos, el qual ha de dirimir la disputa (ह̌ı $\varsigma$ ) sobre qui mereix ocupar el primer lloc ( $\pi \varrho 0 \varepsilon \delta \varrho i ́ \alpha)$ en els afers de la guerra. ${ }^{5}$ Els altres dos diàlegs presenten alguns trets comuns, atès que, malgrat el canvi d'interlocutor,

\footnotetext{
${ }^{1}$ A tall d'exemple, i darrerament, l'obra de teatre Los bosques de Nyx de Javier Tomeo (1994), El corazón alberga muchas sombras de José María Gironella (1995), o Los inmortales de Manuel Vilas (2012); vid. Unceta Gómez (2014: 27-39).

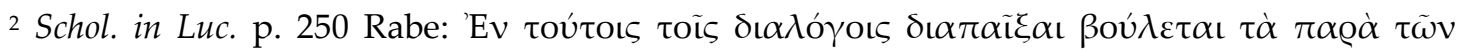

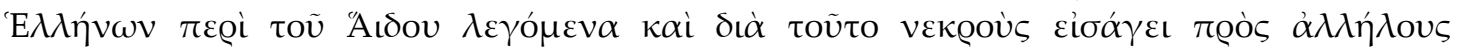

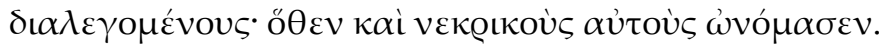

${ }^{3}$ El conjunt s'identifica com l'opus 77 en l'ordenació del manuscrit $\Gamma$ (Vaticanus Graecus 90, s. X), que relaciona les obres del corpus llucianesc del número 1 al 80 .

${ }^{4}$ Aquests diàlegs corresponen en la numeració del manuscrit $\Gamma$ als números 12 , 13 i 25; en la tradició $\beta$ són el 14 (amb canvi d'ordre en el títol, Alexandre i Filip), el 13 (també amb canvi d'ordre en el títol (Alexandre i Diògenes) i el 12, en el títol del qual només són esmentats Alexandre i Anníbal. Gonzàlez Julià (2011: 357-379) proposa llegir com escenes distintes d'una mateixa una seqüència organitzada les peces que integren els Diàlegs de morts; per a una aplicació d'aquesta proposta als Diàlegs de déus, vegeu GóMEZ (2012: 117-138).

${ }^{5}$ Inspirat en aquest diàleg, a finals del s. XV, Filippo Lapaccini va escriure un Certamen inter Hannibalem et Alexandrum ac Scipionem Aphricanum, probablement, per a una representació teatral; vid. Bosisio (2014: 125-65).
} 
en ambdues peces es fa referència a l'ascendència d'Alexandre, al seu caràcter i capteniment.

Pel que fa a la nissaga d'Alexandre, les paraules del rei Filip i del filòsof Diògenes posen de manifest que la presència d'Alexandre a l'Hades, per ella mateixa, invalida qualsevol credibilitat sobre una possible progènie divina i un origen sobrenatural del macedoni, perquè desmenteix la tradició que el feia fill del déu Ammó, així com la relativa a una extraordinària concepció, resultat de $1^{\prime}$ acoblament de la reina Olimpíada amb una serp. ${ }^{6}$

Llucià presenta Alexandre, un cop mort, confessant a Filip que només va creure els oracles sobre la seva genealogia immortal com una estratègia útil per als seus projectes de conquesta: els bàrbars, si pensaven que lluitaven contra un déu, tenien por, eren més febles i, per tant, més fàcils de derrotar. ${ }^{7}$ Igualment, quan Diògenes li recrimina aquesta tàctica enganyosa, Alexandre admet el seu vertader llinatge:

Luc. DMort. 13.1

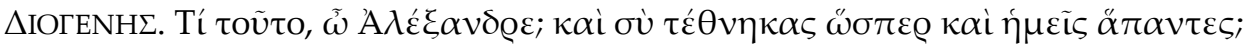

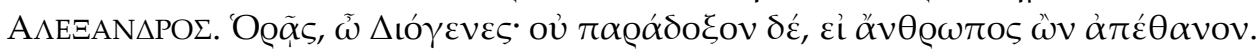
DiòGENES. Què, Alexandre? Tu també ets mort, com tots nosaltres?

ALEXANDRE. Ja ho veus, Diògenes. Però no té res d'estrany que, sent un home, m'hagi mort.

Alexandre renuncia així - circumstàncies obliguen! - al parentiu amb el déu egipci: ell és només un home, fill de mortals i no pas d'Ammó. Altrament, no seria a l'Hades, com Filip li fa notar, no sense sarcasme, en iniciar la conversa amb ell:

Luc. DMort. 12.1

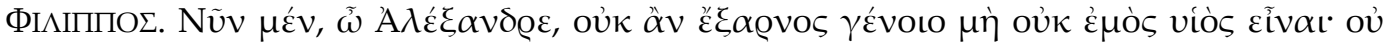

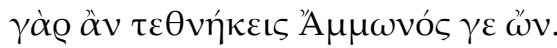

FILIP. Ara, Alexandre, no negaràs que ets fill meu, perquè no series mort si fossis fill d'Ammó.

El desenvolupament d'ambdós diàlegs revela que les paraules d'Alexandre no són sinceres, perquè a l'Hades el jove rei continua solament preocupat per les gestes militars, pel nombre ingent d'enemics abatuts, per les glorioses ferides rebudes, pels béns materials deixats enrere, per la pèrdua d'honors, afalacs $\mathrm{i}$ lloances; ${ }^{8}$ fins i tot té l'esperança de rebre encara un enterrament que el faci de

\footnotetext{
${ }^{6}$ Plutarc (Alex. 2-3) explica que, segons Eratòstenes, Olimpíada, en acomiadar Alexandre per a la gran expedició, li descobrí, únicament a ell, el secret de la seva naixença, i li va encomanar que mostrés uns sentiments dignes d'aquell origen.

7 Luc. DMort. 12.1.

${ }^{8}$ La actitud del macedoni correspon a la de tants d'altres morts quan fan camí a l'inframon. Així ho constaten el barquer Caront o Hermes quan afirmen que és propi dels morts plànyer la seva dissort i, per tant, fins i tot obliguen Micil a creuar l'Estígia gemegant, perquè ell és un humil sabater $\mathrm{i}$ se sent feliç per haver mort, atès que res no tenia mentre vivia. Cf. Luc. Cat. 20: «HERMES. Micil, que no et planys? No és permès a ningú fer aquesta travessa sense llàgrimes.
} 
debò un déu, com explica a Diògenes quan aquest li demana on l'han sepultat els macedonis:

Luc. DMort. 13.3

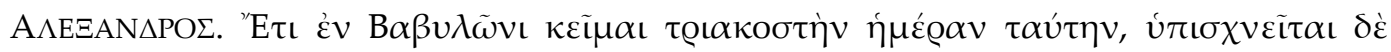

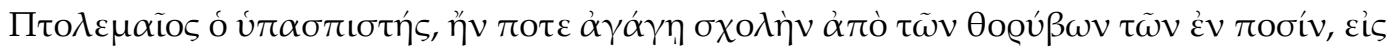

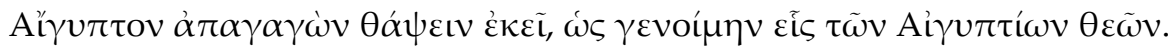

AleXANDRE. Ja fa trenta dies que descanso a Babilònia, però Ptolomeu, el meu assistent, m'ha promès que així que hagi passat el caos actual i tingui una mica de temps, se m'endurà a Egipte, m'hi enterrarà i em convertiré en un déu dels egipcis.

El caràcter irat i violent d'Alexandre, sensible a tota mena d'adulacions, queda reflectit, també en ambdós diàlegs, en l'esment que tant Filip com Diògenes fan a Clitos, un dels generals macedonis que formava part del grup dels

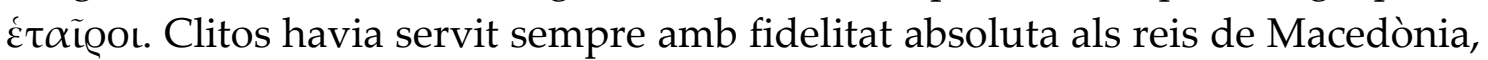
primer a Filip, i després a Alexandre - fins i tot li va salvar la vida en el primer enfrontament amb els perses en terra asiàtica, a la batalla del Grànic (334 aC). Alexandre, però, l'assassinà durant un banquet celebrat a Maracanda perquè gosà desafiar-lo: Clitos li retreia una excessiva inclinació envers els usos bàrbars i, sobretot, que permetés cants de burla contra els generals macedonis derrotats en el setge d'aquella ciutat. ${ }^{9}$

En el diàleg de Llucià entre els dos reis, Alexandre vol que el seu pare li reconegui la grandesa de les gestes complides: «vaig sotmetre els grecs sense vessar una sola gota de sang, i els tebans ja deus haver sentit com els vaig tractar»

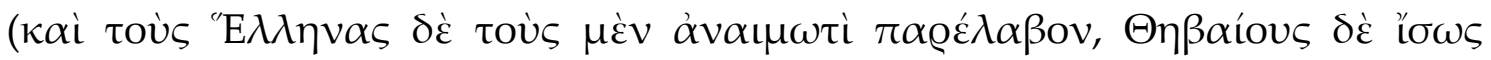

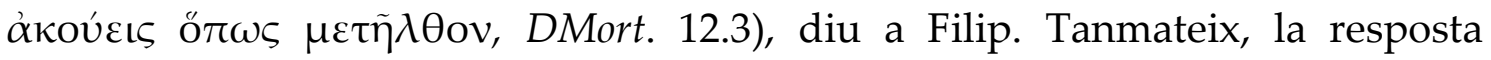
d'aquest no pot satisfer Alexandre:

Luc. DMort. 12.3

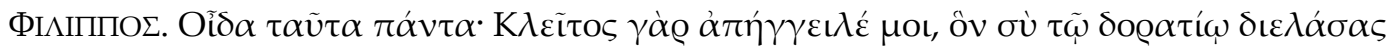

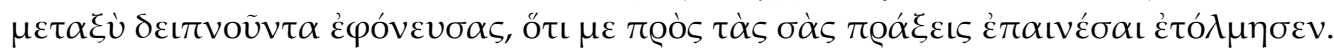

FILIP. Tot això, ho sé. M’ho va explicar Clitos, a qui vas matar en un sopar, traspassant-lo amb la llança, perquè gosà lloar-me a mi, abans que les teves gestes.

Per la seva banda, Diògenes, en comprovar l'enyor i la tristor d'Alexandre, a l'Hades estant, per la vida perduda, li aconsella que begui aigua de la font de l'Oblit $(\Lambda \eta ́ \theta \eta)$ i així podrà deixar de patir per la gran nostàlgia que li provoca el

MiCIL. I ara! Amb tan bona navegació, no m’he de lamentar per res! HERMES. Tot i així, gemega una miqueta, com és costum. MicIL. D'acord doncs, em lamentaré, Hermes, ja que et sembla escaient fer-ho. Ai las, les meves sabates! Ai, les meves velles botes! Ai, ai, ai les meves sandàlies fetes pols! Dissortat de mi, mai més ja no estaré dejú, des del matí fins la nit, ni aniré amunt i avall descalç a l'hivern, mig nu, cruixint de dents pel fred. Qui tindrà ara la meva tissora i el meu punxó?».

${ }^{9}$ Cf. Arr. An. IV 3.7. Segons Plutarc, Clitos era home de tarannà violent i en aquella ocasió estava

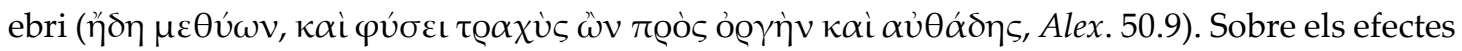
del vi, la llibertat de paraula i el comportament d'Alexandre, vegeu Gómez i Mestre (2009: 215218). 
record de la vida terrenal, però, sobretot, perquè - com li adverteix el filòsof«veig que s'acosten cap a tu Clitos, Cal-lístenes i molts altres per a fer-te bocins i

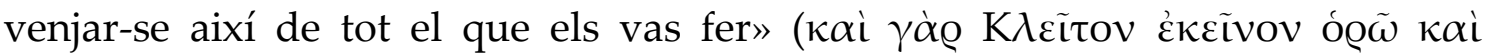

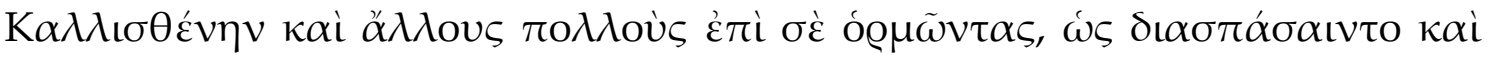

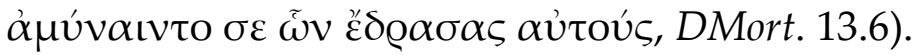

\section{FRANÇOIS DE SALIGNAC DE LA MOTHE-FÉNELON (1651-1715)}

Un salt en el temps ens porta primer fins a la França del s. XVII. Abans, però, l'editio princeps de les obres de Llucià, el 1496 a Florència sota la cura de J. Làscaris, a la impremta de Lorenzo di Alopa, marca l'inici d'una significativa presència de l'autor de Samòsata en les lletres europees ja des de les primeries del Renaixement. ${ }^{10}$ Els dialogi minores mereixeren aleshores una especial atenció, com desvetlla una estreta relació, per exemple, entre la representació plàstica, pictòrica i escultòrica, de determinats mites i contalles clàssiques amb les versions que n'ofereix Llucià en els Diàlegs de déus o en els Diàlegs marins. ${ }^{11}$ Els Diàlegs de morts no foren pas una excepció en la difusió de l'obra del samosatenc, especialment per la vessant crítica i satírica - diguem-ne, de caire més filosòfic $-{ }^{12} \mathrm{~d}$ 'aquestes breus peces, en les quals, des de la distància i alteritat que representa el reialme de Plutó, es fa patent la veritat amagada que tota sàtira pretén sempre portar a la llum, sobre individus concrets, sobre usos o costums generals, sobre determinades maneres de procedir, d'ostentar el poder, de practicar la religió. El més enllà és un espai utòpic i ucrònic que fa possible escorcollar aquesta veritat, examinant el genuí caràcter i autèntic valor dels homes, un cop han estat ja desproveïts de qualsevol l'embolcall terrenal; ${ }^{13} \mathrm{i}$, a un mateix temps, permet menysprear-ne tota vanaglòria supèrflua, o qüestionar el deler amb què s'afanyaven en vida pels béns materials - com hem vist que feia Alexandre. ${ }^{14}$

El valor crític, instructiu i alhora moralitzant, que té la sàtira subjacent en els Diàlegs de morts de Llucià, fa que aquesta obra hagi estat una de les més

\footnotetext{
10 Vid. Vives Coll (1959); Robinson (1979); Vian Herrero (2005: 51-95).

11 Vid. Faedo (1994: 129-142).

${ }^{12}$ Com posa de manifest la influència de Llucià en un esperit crític com Erasme de Rotterdam, que va traduir alguns diàlegs del samosatenc (Paris, 1506) i el va imitar en diversos escrits seus com els Collectanea Adagiorum (1500-1536), Morias enkonion (1509-1511), o els Colloquia Familiaria (1517-1530). En un d'aquests col-loquis, intitulat Charon (publicat el 1523), mitjançant una conversa entre el barquer de l'Estígia i el geni infernal Alàstor, Erasme denuncia la guerra estesa per Europa com a conseqüència de l'ambició i dels desacords entre els monarques d'Espanya, França i Anglaterra; vid. Grigoriadu (2009: 149-151).

${ }^{13}$ A tall d'exemple, Luc. Nec. 17, Luct. 14-19, DMort. 29. Vid. Camerotto (2016: 9-26); Gómez (2016: 97-128).

${ }^{14}$ Cf. DMort. 13.6. En l'obra Caront o els contempladors, Llucià presenta Caront de visita a la terra, ja que el barquer, deixant les seves obligacions a l'Estígia, desitja conèixer, de primera mà, per què els homes es resisteixen a deixar la vida; vid. Gómez (2012: 13-29).
} 
imitades del samosatenc tant en el seu format com en el seu propòsit, i li doni vigència de clàssic, de manera que en cada nova imitació directa, adaptació, o fins i tot velada al-lusió, els autors posteriors han pogut crear noves converses fantasmals, acomodant-les a la particular intenció i finalitat de la seva obra, a la realitat de la seva època.

Així, Fénelon publicà entre 1692 i 1696 uns Dialogues des morts, compostos per a l'educació de l'arrogant i indisciplinat duc de Borgonya (1682-1712), Lluís de França, net de Lluís XIV i fill del Gran Delfí (1661-1711); per tant, futur rei de França.

Potser per aquesta circumstància també en aquests Dialogues des morts Alexandre el Gran reviu, ja que en quatre diàlegs, entre els protagonitzats per figures il·lustres de l'Antiguitat, $^{15}$ n'és interlocutor principal, i hi apareix conversant amb el seu mestre Aristòtil (XXV), amb Clitos (XXVI), amb Diògenes (XXVII) i amb Cèsar (XLII). En tots aquests diàlegs l'autor, pel propòsit didàctic i pedagògic de la seva obra, insisteix en els perills que l'adulació, l'orgull i la incontinència de les passions comporten sempre en l'exercici del poder, tal com reflecteix l'ensenyament moral que encapçala aquests diàlegs en l'edició Didot de 1787: ${ }^{16}$

Alexandre et Aristote (XXV)

Quelque grandes que soient les qualités naturelles d'un jeune prince, il a tout à craindre s'il n'éloigne les flatteurs, s'il ne s'accoutume de bonne heure à résister à ses passions, et à aimer ceux qui auront le courage de lui dire la vérité.

Alexandre et Clitus (XXVI)

Funeste délicatesse des grands, qui ne peuvent souffrir leurs véritables serviteurs lorsqu'ils veulent leur faire connaître leurs défauts.

Alexandre et Diogène (XXVII)

La flatterie est pernicieuse aux princes.

César et Alexandre (XLII)

Caractères d'un tyran, et d'un prince qui, étant né avec les plus belles qualités pour faire un grand roi, s'abandonne à son orgueil et à ses passions. L'un et l'autre sont les fléaux du genre humain ; mais l'un est à plaindre, et l'autre fait l'horreur de l'humanité.

El diàleg amb Clitos revela amb nitidesa que la veritat sempre sura a l'Hades, sobretot perquè Alexandre no accepta la condició de mort i perquè, en reclamar el perdó de Clitos, fa encara més evident que el rei de Macedònia ha actuat de manera indigna envers un lleial servidor. En efecte, en el text de Fénelon - com en el de Llucià - Alexandre segueix encegat encara pel desig de fama i enlluernat pels aduladors, com expressa Clitos:

\footnotetext{
15 Els Dialogues des morts inclouen també converses entre personatges de la història moderna com cardenals i papes (Richelieu, Cisneros, Sixte V), reis de França (Carles VII, Francesc I, Lluís XI, Lluís XII), o reis d'Anglaterra (Ricard II, Enric VII, Enric VIII), entre d'altres.

${ }_{16}$ CEuvres de M. de Fénelon, tome IV, Paris, Didot, 1787.
} 
Fénelon, Dialogues des morts [Alexandre et Clitus]

CLITUS. [...] je te reconnais pour un grand conquérant, d'un naturel sublime, mais gâté par de trop grands succès. Te dire la vérité avec affection, est-ce t'offenser. Si la vérité t'offense, retourne sur la terre chercher les flatteurs.

Però alhora, la imatge del macedoni a l'inframon posa en valor la caducitat de l'existència humana, més dolorosa precisament per als qui han gaudit de privilegis o han ostentat cotes de màxim poder: ${ }^{17}$ «sur la terre j'étais un dieu ! ici je ne suis plus qu'une ombre !», s'exclama Alexandre.

Aquesta peça del preceptor francès entre Alexandre i Clitos construeix i desenvolupa una escena ja pressentida en les paraules pronunciades per Diògenes al final del diàleg de Llucià entre el filòsof i el rei, ${ }^{18}$ ja que Fénelon acara assassí i víctima en el seu diàleg. Tanmateix, el recel de Diògenes - en el text de Llucià advertia d'una possible acció violenta de Clitos - no es compleix - en part, el propi Clitos en donarà les raons: Alexandre és mort i un mort no pot tornar a morir!,$-{ }^{19}$ de manera que la violència de Clitos es redueix, en el text francès, a l'àmbit verbal. Tanmateix, la presencia del general resulta enutjosa per a Alexandre perquè li recorda per sempre més el crim ignominiós que ha comès: «Ah ! Clitus, retire-toi ; je ne puis supporter ta vue ; elle me reproche ma faute. [...] O la cruelle compagnie! Voir toujours un homme qui rappelle le souvenir de ce qu'on a eu tant de honte d'avoir fait !». Aquesta visió significa, però, la pròpia condemna del macedoni, com precisa un serè - i irònic- Clitos en resposta al trasbalsament d'Alexandre:

Fénelon, Dialogues des morts [Alexandre et Clitus]

CLITUS. Pluton veux que je demeure davant tes yeux, pour te punir de m'avoir tué injustement. J'en suis fâché ; car je t'aime encore, malgré le mal que tu m’as fait ; mais, je ne puis plus te quitter.

Per a Clitos, en canvi, l'encontre amb el rei possibilita poder parlar-hi obertament, amb la llibertat i franquesa que caracteritza també els personatges infernals de Llucià que assumeixen el paper d'heroi satíric, com solen fer Menip o Diògenes: ${ }^{20}$

${ }^{17}$ Com Llucià descriu, per exemple, en la figura del tirà Megapentes de l'obra intitulada $L a$ travessia o el tirà. Per a una proposta d'identificació d'aquest tirà, vegeu Mestre i Gómez (2009: 93-107).

${ }^{18}$ Cf. DMort. 13.6; supra n. 14.

19 «ALEXANDRE. Quoi! le grand Alexandre ! faire pitié à un homme vil tel que Clitus! Que ne puis-je ou le tuer ou me tuer moi-même ! CLITUS. Tu ne peux plus ni l'un ni l'autre; les ombres ne meurent point».

${ }^{20}$ Luc. DMort. 2, 13, 20, 22, 29, 30. Sobre Menip com a heroi satíric, vegeu Camerotto (2014: 4083); Deriu (2017: 37-50). 
Fénelon, Dialogues des morts [Alexandre et Clitus]

CLiTUS. [...] il n'est plus temps d'être délicat sur les bords du Styx. Il fallait quitter cette délicatesse en quittant la grandeur royale. Tu n'as plus rien à donner ici, et tu ne trouveras plus de flatteurs.

Les paraules del general provoquen Alexandre, que veu com ara és, fins i tot, objecte de retrets, ${ }^{21}$ però alhora il-lustren la incapacitat absoluta del monarca, al llarg del diàleg, per entendre i acceptar quina és la situació present, per conformar-se a admetre on ha anat a raure el seu poder, i per saber suportar que per als homes existeix només una eternitat, la de la mort:

Fénelon, Dialogues des morts [Alexandre et Clitus]

CLITUS. [...] les ombres ne meurent point : te voilà immortel, mais autrement que tu l'avais prétendu. Il faut te résoudre à n'être qu'une ombre comme moi, et comme le dernier des hommes. Tu ne trouveras plus ici de provinces à ravager, ni de rois à fouler aux pieds, ni de palais à brûler dans ton ivresse, ni de fables ridicules à conter, pour te vanter d'être le fils de Jupiter.

Filip, en acabar la conversa amb el seu fill i successor, ja preludiava en el text de Llucià aquesta inadaptació d'Alexandre, bo i reprenent-lo en els termes següents:

Luc. DMort. 12.5

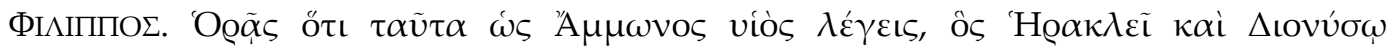

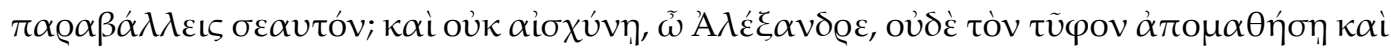

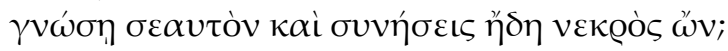

FILIP. ¿Veus que dius això com si fossis fill d'Ammó, i et compares amb Hèracles i Dionís? ¿I no te n'avergonyeixes, Alexandre? ¿No deixaràs de banda aquests fums, et coneixeràs a tu mateix i comprendràs que ja ets només un mort?

També Clitos destaca, en el text de Fénelon, l'excessiva estima de si mateix que mostra Alexandre: «Te voilà aussi colère et aussi fougueux que tu étais parmi les vivants. Mais personne ne te craint ici ; pour moi, tu me fais pitié». Però sobretot el general denuncia com la supèrbia, l'orgull i l'indigne comportament $\mathrm{d}^{\prime}$ Alexandre foren, en definitiva, la causa de la pròpia dissort del conqueridor: ${ }^{22}$

Fénelon, Dialogues des morts [Alexandre et Clitus]

ALEXANDRE. Tu me traites comme un misérable. [...] A quoi donc me servira toute ma gloire, si Clitus même ne m'épargne pas?

${ }^{21}$ «ALEXANDRE. Ah! Quel malheur! Sur la terre j'étais un dieu ! Ici je ne suis plus qu'une ombre, et on m'y reproche sans pitié mes fautes».

${ }^{22}$ En el diàleg de Llucià, Filip només reconeix com a exemplar l'actitud d'Alexandre davant les dones de la família de Darios, un motiu que també tracta Plutarc (Alex. 21), i és reprès en el text de Fénelon: «CLITUS. [...] Quand tu parus si chaste à la vue de la femme et de la fille de Darius, quan tu montras tant de générosité pour ce prince vaincu, tu méritas de grandes louanges ; je te les donne. Ensuite la gloire te fit tourner la tête». 
CLITUS. C'est ton emportement qui a terni ta gloire parmi les vivants. Veux-tu la conserver pure dans les Enferns, il faut être modeste avec des ombres qui n'ont rien à perdre ni rien à gagner avec toi.

\section{JORGE LUIS BORGES (1899-1986)}

Així mateix, si fem encara un altre salt en el temps, de nou és possible d'identificar l'obstinació d'Alexandre a no tolerar els condicionaments inseparables del traspàs de qualsevol individu, en l'afirmació següent: «-A mí me basta ser el que soy - dijo Rosas-, y no quiero ser otro». Aquests mots apareixen en una peça, precisament intitulada Diálogo de muertos, ${ }^{23}$ on Jorge Luis Borges fa conversar, també un cop morts, dos protagonistes destacats de la història argentina del s. XIX, un període marcat per les guerres intestines posteriors a la independència del país, aconseguida el 1816. Es tracta de Juan Manuel de Rosas, governador de la província de Buenos Aires, i Juan Facundo Quiroga, polític i militar de la província argentina de La Rioja, l'acció i conducta dels quals generà notable controvèrsia i disparitat d'opinions entre els seus coetanis. $^{24}$

Borges - com fa Llucià en molts dels seus diàlegs - no esmenta, a l'inici del text, el nom dels interlocutors; en descriu només alguns trets o en dona determinades pinzellades biogràfiques, a través dels quals els lectors poden reconèixer-los:

\section{J. L. Borges, Diálogo de muertos}

El hombre llegó del sur de Inglaterra en un amanecer del invierno de 1877. Rojizo, atlético y obeso, resultó inevitable que casi todos lo creyeran inglés y lo cierto es que se parecía notablemente al arquetípico John Bull.

Així comença el Diálogo de muertos, amb la presentació de Rosas, mort a l'exili el 14 de març de 1877 a Southampton. ${ }^{25}$ El lloc on arriba el polític i militar, és el més enllà: els qui el reben han patit una mort violenta — «a muchos les rayaba la garganta una línea roja, otros no tenían cabeza»-, tal vegada com a conseqüència de l'actuació del nouvingut; per tant, ara, en l'escena literària del diàleg, són només ombres: «andaban con recelo y vacilación, como quien camina en la sombra». Però, com Clitos enfront d'Alexandre, las víctimes podran veure, a la fi, el seu botxí en igualtat de condicions:

\footnotetext{
${ }^{23}$ Aquest diàleg forma part de El hacedor, un conjunt de cinquanta-cinc poesies, assajos i relats publicats l'any 1960. El text és citat en aquest treball per l'edició Jorge Luis Borges, El hacedor, Barcelona, Debolsillo, 2012.

24 Vid. Torres Molina (1999).

${ }^{25}$ L'exili de Rosas fou provocat per la derrota de l'exèrcit de Buenos Aires en la batalla de Caseros (1852) i permeté la redacció de la Constitució Nacional de 1853, promulgada per Justo José de Urquiza, un opositor de Rosas.
} 
J. L. Borges, Diálogo de muertos

Un grupo de hombres, de mujeres y de criaturas lo esperaba con ansiedad; [...] Fueron cercando al forastero y, desde el fondo, alguno vociferó una mala palabra, pero un terror antiguo los detenía y no se atrevieron a más.

Aleshores és introduït, també sense donar-ne el nom, el segon interlocutor, Juan Facundo Quiroga:

\section{J. L. Borges, Diálogo de muertos}

A todos se adelantó un militar de piel cetrina y ojos como tizones; la melena revuelta y la barba lóbrega parecían comerle la cara. Diez o doce heridas mortales le surcaban el cuerpo como las rayas en la piel de los tigres. ${ }^{26}$

Borges recupera la forma dialògica com a vehicle òptim per tal que aquests dos polítics de la Confederació Argentina, mesurin, a l'inframon i a força de paraules, el paper que cadascú d'ells desenvolupà en els esdeveniments històrics. ${ }^{27}$ Però no es tracta només de fer perdurable post mortem la rivalitat pel poder, de mantenir viva l'heroïcitat de les gestes abrivadament comeses - «Mi imperio fue de lanzas y de gritos y de arenales y de victorias casi secretas en lugares perdidos», recorda Quiroga -, ni de reflexionar sobre el sentit de la fama de la posteritat — «El halago de la posteridad no vale mucho más que el contemporáneo, que no vale nada y que se logra con unas cuantas divisas», afirma Rosas-, sinó que la força del diàleg rau sobretot en que la conversa enfronta, definitivament amb total franquesa, víctima i assassí.

Rosas, presumpte artífex de l'emboscada on va morir el cabdill de la província de La Rioja i que a ell mateix li resultà favorable per refermar la seva hegemonia, ${ }^{28}$ parla només de traïció («-¡Qué aflicción ver a un guerrero tan espectable derribado por las armas de la perfidia!») i es vanta alhora d'haver venjat, en exercici del seu poder, la mort del seu infernal interlocutor: «iPero también qué íntima satisfacción haber ordenado que los victimarios purgaran sus fechorías en el patíbulo, en la plaza de la Victoria!».

\footnotetext{
${ }^{26}$ Els enemics de Quiroga el sobrenomenaren el 'Tigre de los Llanos' per a indicar la seva crueltat i manera de fer despietada; els seus amics, per a destacar-ne el coratge i valentia.

${ }^{27}$ Altres mostres d'aquesta tradició a Llatinoamèrica són, per exemple, un text que al s. XIX circulava de forma anònima, intitulat Diálogo entre Atahualpa y Fernando VII en los Campos Elíseos, de l'advocat, polític, militar i revolucionari argentí, Bernardo de Monteagudo (1789-1825); o els Diálogos de diversos muertos sobre la Independencia de América de l'hondureny José Cecilio del Valle (1777-1834). El 1996, a Brasil, María Celeste Consolin Dezotti publicà una traducció integral dels Diàlegs de morts de Llucià, completada el 2003 amb l'adaptació feta per a la representació teatral, que és analitzada per Fernández Robbio (2012: 203-209).

${ }^{28}$ Quiroga fou assassinat el 16 de febrer de 1835 a Barranca Yaco (Córdoba) com a conseqüència d'un complot orquestrat pels germans Reinafé, els quals foren executats posteriorment per Rosas, qui obtingué com a resultat positiu d'aquests esdeveniments un enfortiment notable del seu poder.
} 
Quiroga, en canvi, no dubta que el responsable directe de la seva mort fou el governador de la província de Buenos Aires, tot i que a ell mateix li serví per a consolidar-se com a llegenda:

\section{J. L. Borges, Diálogo de muertos}

A usted le debo este regalo de una muerte bizarra, que no supe apreciar en aquella hora, pero que las siguientes generaciones no han querido olvidar. No le serán desconocidas a usted unas litografías muy primorosas y la obra interesante que ha redactado un sanjuanino de valía. ${ }^{29}$

Com en el text de Llucià o de Fénelon, també en l'escrit de Borges l'enfrontament dialèctic entre ambdós cabdills descobreix, en l'altra vida, la veu crítica, especialment provocadora, d'un dels interlocutors, ${ }^{30}$ perquè Quiroga, home d'acció militar, és conscient d'haver assolit el seu lideratge - i condició heroica - bregant sense por:

\section{J. L. Borges, Diálogo de muertos}

A usted le tocó mandar en una ciudad, que mira a Europa y que será una de las más famosas del mundo; a mí, guerrear por las soledades de América, en una tierra pobre, de gauchos pobres. ${ }^{31}$

Amb aquestes paraules, Quiroga intenta posar en evidència la covardia, l'engany, les conxorxes i les conspiracions que han dirigit l'acció de govern de Rosas, tot i que aquest - sembla - ja n'és plenament conscient, si hem de jutjar per la seva rèplica:

\section{J. L. Borges, Diálogo de muertos}

Yo no necesito ser valiente. Una lindeza mía, como usted dice, fue lograr que hombres más valientes que yo pelearan y murieran por mí. Santos Pérez, pongo por caso, que acabó con usted. El valor, es cuestión de aguante; unos aguantan más y otros menos, pero tarde o temprano todos aflojan.

D'altra banda, el text de Borges formula clarament - i de nou en boca de Quiroga - el sentit autèntic i, per tant, l'efecte veritable d'una conversa a l'inframon. Si Filip recriminava la tossuderia del seu fill recordant la màxima

\footnotetext{
${ }^{29}$ Domingo Faustino Sarmiento va escriure un pamflet polític intitulat Facundo o civilización y barbarie en las pampas argentinas (Xile, 1845), on retrata la personalitat complexa de Quiroga.

${ }^{30}$ Com en els Diàlegs de morts de Llucià fan sovint Diògenes o Menip, la veu del qual fins i tot provoca les queixes dels seus veïns de l'Hades; cf. Luc., DMort. 3.1: «CRESOS. No podem suportar més, Plutó, aquest gos, Menip, el nostre veí, de manera que o te l'emportes o serem nosaltres els qui canviarem de residència. PLUTó. Però ¿Quin mal us fa, si és un cadàver igual que vosaltres? CRESO. Cada cop que nosaltres gemeguem i ens lamentem recordant els béns d'allà dalt -Midas, or, Sardanàpal, un gran luxe, i jo, Cresos, tresors, Menip es riu de nosaltres, ens insulta, tractant-nos d'esclaus i d'escòria; de vegades fins i tot es posa a cantar per entorpir els nostres gemecs. En resum, és un corcó».

${ }^{31}$ Cf. els versos del propi J. L. Borges en el poema El general Quiroga va en coche al muere (Luna de enfrente, 1925): «...Yo, que he sobrevivido a millares de tardes / y cuyo nombre pone retemblor en las lanzas, / no he de soltar la vida por estos pedregales...».
} 
dèlfica $\gamma v \tilde{\omega} \theta$ ı $\sigma \varepsilon \alpha v \tau o ́ v,{ }^{32}$ també Rosas escolta sense immutar-se les paraules acusadores del seu adversari i es dona per satisfet de la seva obra de govern («Rosas no le hizo caso»). Aleshores Quiroga invoca de forma decisiva quelcom inherent a les converses en el més enllà, fora del món físic perceptible pels sentits: l'aprenentatge que vehicula el miratge literari de l'altra vida. Així s'entén la resignada afirmació de Quiroga quan Rosas malda per mantenir-se fidel a la seva manera d'actuar, pensant que el diàleg d'ara amb qui era el seu enemic mentre eren vius, no és més que un somni: ${ }^{33}$

\section{J. L. Borges, Diálogo de muertos}

-También las piedras quieren ser piedras para siempre - dijo Quiroga - y durante siglos lo son, hasta que se deshacen en polvo. Yo pensaba como usted cuando entré en la muerte, pero aquí aprendí muchas cosas.

Perquè Quiroga ha après la necessària mutació que implica el més enllà, on ara ell mateix opta per renunciar a conductes que ja no li tenen cap efecte: ${ }^{34}$

\section{J. L. Borges, Diálogo de muertos}

- Así era - dijo Quiroga -, pero yo he vivido y he muerto y hasta el día de hoy no sé lo que es miedo. Y ahora voy a que me borren, a que me den otra cara y otro destino, porque la historia se harta de los violentos. No sé quién será el otro, qué harán conmigo, pero sé que no tendrá miedo.

El recorregut dut a terme fins aquí - certament, parcial i limitat - posa de manifest la versàtil riquesa d'una dilatada tradició de converses espectrals, nascuda, sense dubte, amb vocació satírica, però capaç també d'incloure altres objectius, perquè les paraules dels seus protagonistes - precisament per la seva condició de morts $-{ }^{35}$ amaguen sempre un pregon significat. Tal vegada sigui una certa por a esbrinar quin és aquest significat, allò que explica l'actitud d'Alexandre als inferns tant en el text de Llucià com en el de Fénelon, o que

\footnotetext{
${ }^{32}$ Luc. DMort. 12.5: «FILIP. ¿Veus que dius això com si fossis fill d'Ammó, i et compares amb Hèracles i Dioní? ¿I no te n'avergonyeixes, Alexandre? ¿No deixaràs de banda aquests fums, et coneixeràs a tu mateix i comprendràs que ja ets només un mort?».

33 «...estos lugares y esta discusión me parecen un sueño, y no un sueño soñado por mí sino por otro, que está por nacer todavía», afirma Rosas.

${ }^{34}$ Quan Menip, decebut per l'ensenyament i actituds dels filòsofs, davalla a l'Hades per tal de conèixer quin és el millor gènere de vida per als homes, no s'està de constatar que Filip de Macedònia és un humil sabater de vell, o bé que el rei Mausol de Cària jeu aixafat pel pes ingent de la seva magnífica tomba (Luc. Nec. 17); vid. Gómez (2016: 118-124).

${ }^{35}$ Com formula Quevedo en el Sueño de la muerte (1627): «Estos son gente que están en el otro mundo y aún no se persuaden a que son difuntos. Maravillóme esta visión, y dije herido del dolor y conocimiento: - Dionos Dios una vida sola y tantas muertes; de una manera se nace y de otra se muere; si vuelvo arriba, yo procuraré empezar a vivir bien por la muerte»; vid. Gómez (2019: 63-64). També Fontenelle en els Dialogues des morts modernes (1683): «Les morts sont gens de grande réflexion tant à cause de leur expérience que de leur loisir»; vid. Carruesco i Reig (2010: 49-61).
} 
justifica les paraules que Rosas ja no adreça al seu interlocutor, sinó que diu per a ell mateix:

\author{
J. L. Borges, Diálogo de muertos \\ -Será que no estoy hecho a estar muerto...
}

\title{
BIBLIOGRAFIA
}

BosisIO, M. (2014), «Scipione a corte: il Certamen inter Hannibalem et Alexandrum ac Scipionem Aphricanum di Filippo Lapaccini», Carte Romanze, 2(2), 125-165.

CAMERotto, A. (2014), Gli occhi e la lingua de la satira. Studi sull'eroe satirico in Luciano di Samosata, Milano-Udine, Mimesis Edizione [Classici Contro, n. 2].

CAmerotto, A. (2016), «L'utopia dell'aldilà in Luciano de samosata», AOFL, XVI(1), 926.

CARruesco, J. I ReIG, M. (2010), «Fontenelle i els Nous Diàlegs dels Morts: unes Vides Paral·leles a la manera de Llucià», a Lucian of Samosata. Greek Writer and Roman Citizen, Mestre, F. i Gómez, P. (eds.), Barcelona, Publicacions i Edicions de la Universitat de Barcelona, 49-61.

DERIU, M. (2017), Mixis e poikilia nei protagonisti della satira, Trento, Università degli Studi di Trento [Collana Labirinti, n. 169].

FAEDO, L. (1994), «Le immagini dal testo», a Luciano di Samosata. Descrizioni di opere d'arte, Maffei, S. (ed.), Torino, Einaudi [Nuova Universale Einaudi, n. 217], 129-142.

FERNÁNDEZ RoBBIO, M. S. (2012), «Del diàlogo al texto dramático: una adaptación brasileña de los Diálogos de los muertos de Luciano de Samosata», a De ayer a hoy. Influencias clásicas en la literatura, López, A., Pociña, A. i Silva, M. de Fátima (coords.), Coimbra, Coimbra University Press, 203-209.

GómEZ, P. (2012), «El aprendiz de rapsodo, o de cuando Homero cruzó la laguna Estigia (Lucianus, Cont. 7)», Emerita, LXXX(1), 13-29.

GómEZ, P. (2012), «Secrets de família: amor i poder als Diàlegs de déus de Llucià», a

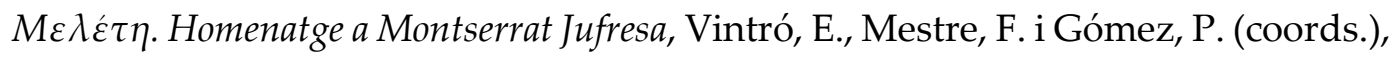
Barcelona, Edicions i lublicacions de la Universitat de Barcelona, 117-138.

GÓMEZ, P. (2016), «Voces del Hades, decretos del más allà: la consulta a los muertos en Luciano», Revista de Estudios Clásicos, 43, 97-128.

GóMEZ, P. (2019), «Menippus, a truly live ghost in Lucian's Necromancy», a Visitors from beyond the Grave: Ghosts in World Literature, Romero González, D., Muñoz Gallarte, I. i Laguna Mariscal, G. (eds.), Coimbra, Coimbra University Press, 47-64.

GómeZ, P. I MESTRE, F. (2009), «The Banquets of Alexandre», a Symposion and Philanthropia in Plutarch, Ribeiro Ferreira, J., Leâo, D., Troster, M. i Barata Dias, P. (eds.), Coimbra, Coimbra University Press, 211-222.

GONZÀLEZ JULIÀ, Ll. (2011), «Luciano ensaya la novela escénica: apariencia episódica y estructura unitaria de los Diálogos de los muertos», Emerita, LXXIX(2), 357-379.

GRIGORIADU, T. (2009), «El Carón de Erasmo traducido por Juan de Aguilar Villaquirán: edición y estudio de la única traducción áurea del coloquio Charon de Erasmo de Rotterdam», Criticón, 106, 147-159. 
MEstRe, F. I GóMEZ, P. (2009), «Power and the abuse of Power in the Works of Lucian», a A Lucian for our Times, Bartley, A. (ed.), Cambridge, Cambridge Scholars Publishing, 93-107.

ROBINSON, CH. (1979), Lucian and his Influence in Europe, London, Duckworth.

TORRes MOlinA, R. (1999), Juan Facundo Quiroga: de la leyenda a la historia, La Plata, Al Margen.

UNCETA GómeZ, L. (2014), «Diálogos de las muertas. Los bosques de Nyx de Javier Tomeo», Aletria, 24(1), 27-39.

ViAn HeRrero, A. (2005), «El diálogo lucianesco en el Renacimiento español: Su aportación a la literatura y el pensamiento modernos», a El diálogo renacentista en la Península Ibérica/Der Renaissancedialog auf der Iberischen Halbinse, Friedlein, R. (ed.), Stuttgart, Steiner, 51-95.

Vives COLL, A. (1959), Luciano de Samosata en España (1500-1700), Valladolid, SeverCuesta. 